\title{
Rutledge pearson and the effort to save Jacksonville "If there is no struggle, there is no progress"
}

\section{Introduction}

Rutledge Pearson was the critical alchemy, which brought about racial progress in Jacksonville, Florida. His leadership of the state and local NAACP came during the most critical period in African American civil rights struggle in Florida. Pearson was able to inspire both youth and adults to engage in civil rights protest designed to recreate American society and end the long history of segregation. Rutledge Henry Pearson was born on September 6, 1929 in Jacksonville, Florida, the youngest son of Lloyd Pearson's sons. He attended the local elementary and middle schools before graduating from Stanton High School in 1947. He then attended Houston-Tillotson College in Austin, Texas, where he received a BA in Political Science in 1951. While at Houston-Tillotson, Pearson served as a charter member of the Student Christian Association and Student Representative to the World Religious Ecumenical Conference at the University of Kansas. Pearson, a gifted singer with a booming bass voice, also sang with the college choir and quartet while serving as senior class president. ${ }^{1}$

An outstanding athlete, Pearson had skills in several sports. However, it was on the baseball field where he truly shined. Pearson's baseball talents attracted attention from professional scouts. In 1952, Abe Saperstein signed him to a one-year contract to play with the Harlem Globetrotters baseball team. Abe Saperstein was a booking agent and promoter who signed players for several basketball and baseball teams. He is most known for his work in starting the Harlem Globetrotters. Saperstein eventually moved on to baseball becoming the principal booking agent for the Negro Baseball Leagues. After one year Saperstein shifted Pearson to the Chicago Giants of the now defunct Negro-American League, where he became a superstar playing first base. He impressed scouts with his. 310 batting average and flawless field play. After his mother became ill Pearson returned to Jacksonville, hoping to join the recently integrated major leagues. He accepted a contract to play for the Jacksonville Beach Seabirds in the previously all-White Class C Florida State League. Unfortunately, Jacksonville's powerbrokers were not ready to integrate the city's baseball team. On the day before spring practice began, the local ballpark closed to prevent Pearson from playing. This move prematurely ended Pearson's baseball career and turned him into a fierce opponent of segregation and racism. Pearson described the event as the "turning point in his life. ${ }^{2}$

With his baseball career over Pearson, like other educated Blacks, had three choices. He could work for the post office, railroad, or school system. He chose to teach and accepted a job teaching Social Studies at Darnell-Cookman Jr. High School. He also coached baseball for Stanton High School where he led the team to two state finals' appearances. Pearson taught at several schools in Jacksonville and eventually rose to head of the Social Studies Department at Darnell-Cookman, and vice-president of the Social Studies Teachers Council of Duval County. As a teacher, Pearson taught African American children about the evils of segregation and racism. $\mathrm{He}$ also served as advisor to the NAACP Youth Council, coordinating its protest activities in Jacksonville. This gave him a chance to involve
Volume 2 Issue 6 - 2018

\author{
Abel A Bartley \\ College of Architecture, Arts \& Humanities, Clemson University, \\ USA
}

Correspondence: Abel A Bartley, College of Architecture,Arts \& Humanities, Clemson University, USA, Tel 864/656-5372, Email abartly@clemson.edu

Received: October 30, 2018| Published: December 31, 2018

teenagers in demonstrations. Pearson wanted to use the NAACP to change Jacksonville. Forcing change on Jacksonville proved difficult. Racial violence coupled with an entrenched conservative leadership left little room for progress in race relations. Many believed that North Florida was too racist to have a strong NAACP chapter. Others argued that Pearson's quiet personality and teaching job disqualified him for NAACP leadership. Pearson accepted a leadership role because he wanted to prove the critics wrong by building a strong NAACP chapter in Jacksonville an area replete with Klansmen, Sons of the Confederacy, and White Citizens Council members. ${ }^{3}$

Pearson's influence was not just limited to the local community. Pearson also served as the state president of the NAACP. This expanded his footprint and made him a much large target of those who opposed Civil Rights. Patricia Pearson his daughter said, "I remember that we received several phone calls over the years from the Confederate underground, saying that we were going to die." ${ }^{4}$ Pearson's sports background and affable personality helped him woo people to the NAACP cause. He was especially successful at recruiting young people to the NAACP. Florida's NAACP movement had been slowed by the death of Harry T. Moore in 1954. The organization was in need of a young popular figure to reenergize the organization and lead the movement keeping the group on track. Pearson was one of the few sports heroes to return to the South to participate in Civil Rights activities. He was determined to prove that North Florida could be a center of Civil Rights activity. ${ }^{5}$

Although he faced automatic dismissal for active participation in NAACP activities, Pearson appealed to minority teachers' consciences and recruited a cadre of young educators to aid him in Civil Rights protest. He was the first person to enlist adults to work with the youth council. The teachers made the signs the students used in protest. He used his lectures and lessons to inspire students to fight for social justice and equality. Pearson encouraged students to memorize the Declaration of Independence and important sections of the constitution, then he challenged them to show how the United States followed those principles. The Florida Times Union noted, "Rutledge Pearson taught his students that knowledge was power, and that they could channel that knowledge into forcing national and local leaders to make the Constitution's guarantees apply to black people, too."

Reverend Charles Dailey served as head of Jacksonville's Interdenominational Ministerial Alliance. This organization worked 
very closely with the NAACP in civil rights protest. Dailey came to Jacksonville in 1959 to pastor the Oakland Street Baptist Church. Almost immediately he volunteered his organization in service to help fight for civil rights. The Ministerial Alliance worked with the NAACP and YMCA to improve conditions in Jacksonville for the city's Black residents. Issues that concerned the ministerial alliance were busing in the urban core and better schools for Black children. Pearson preferred to let the Ministerial Alliance sponsor protest because unlike the NAACP they could not be sued. ${ }^{7}$ Dailey described Pearson as the Pied piper who played the music while the ministers marched behind him. In Jacksonville, 27 ministers went to jail for protest activity, however, none of them were White. Local White ministers chose to stay out of most African American Civil Rights protest activity. That was more than any other ministerial alliance organization in the country. The protest usually began at a church where those who were involved received their instructions then prayed for success. Once the meeting ended, the marchers would march from the church to wherever they were protesting. Pearson used several churches for his meetings, and he never had trouble recruiting volunteers. Mary Ann Pearson, his widow, said he never had anyone turn him down when he asked for something. Pearson had charisma, something other leaders just did not have. His personality made it very difficult to say no to him. ${ }^{8}$

In late 1959, sixteen-year-old Rodney Hurst, took over as president of the NAACP's Youth Council. Hurst, an ambitious, but restless young man, symbolized the young people in Jacksonville who were ready to force change on the city. He sat in Pearson's classes learning the evils of segregation. He vividly remembers Pearson saying, "The way to hurt segregation is to hit segregationist in their pockets." In Jacksonville, Blacks wanted to end the humiliation associated with receiving services at White owned enterprises. As Frank Priestly, a teacher recruited by Pearson said, "Not only could we not sit and eat at some lunch counters, but at Stand and Snack, they would not even allow us to stand and eat next to Whites. ${ }^{9}$ Pearson who described himself as a, "man in a hurry" squared off with Jacksonville's long time mayor Haydon Burns who obviously was in no hurry. With 1960 being an election year and Burns was running in the Governor's race it was obvious that the clash between these two men would have national consequences. Like a hungry tiger, Pearson was ready to pounce on the opportunity to wring concessions from Burns. Burns, however, refused to compromise, because he feared the effects of racial compromise on his White power base. Since Burns was running for governor, he knew any compromises would have state impact. Like a cunning snake, Burns chose to delay and use the controversy to enhance his political position. Burns had plenty of support in his opposition to integration. City officials and many local Whites strongly opposed integration. Some residents had threatened violence to halt the protest and maintain the discriminatory system. Earlier in the year school board officials named the city's newest public high school after Nathan Bedford Forrest, the founder of the Ku Klux Klan, an obvious insult to those who supported school integration. ${ }^{10}$

In 1960 Jacksonville, Florida, Haydon Burns entered his eleventh year in office, an office he owed principally to the support of African American voters. Except for appointing a few black police officers and attending select African American functions, Burns gave blacks very little for their loyal support. These small concessions accrued substantial support amongst Black leaders. Burns remained a staunch segregationist and actively resisted all efforts to integrate. His strong support among African American leaders made him almost immune to black criticism. ${ }^{11}$ When Burns entered Florida's governor's race in 1959, he championed conservative social issues. This enhanced his position among white conservatives, but jeopardized his support among blacks. Burns reaffirmed his segregationist position just as Jacksonville's civil rights movement intensified. As he became increasingly resolute in his opposition to integration, AfricanAmerican leaders reacted by organizing protests to force city leaders to integrate. By midyear 1960, the city faced massive protests sponsored by the National Association for the Advancement of Colored People. The NAACP wanted to integrate Jacksonville's public facilities and improve economic opportunities for blacks. ${ }^{12}$

Jacksonville had neither a chapter of the Student Nonviolent Coordinating Committee nor of the Southern Christian Leadership Conference; consequently, the NAACP, which had a long successful history there, led Jacksonville's civil rights campaign. Most black leaders in the city were active members. They felt comfortable handling racial problems locally because they were familiar with city officials. ${ }^{13}$ By 1960 , nearly six years had passed since the United States Supreme Court had outlawed educational segregation, but for African Americans little had changed. Blacks continued to be relegated to the lowest levels of society, as the legal protections afforded even America's newest immigrants were systematically denied them. Throughout the 1950s, the suffocating bands of segregation and discrimination choked the social life out of Black America. Forced to endure second rate educational and social services, Blacks had little hope for improving their lot unless they increased the pressure on policy makers. Those who had once silently accepted second class citizenship loudly expressed their desire for change.

Late in 1959 Burns entered Florida's gubnatorial race. To attract conservatives in Florida's Northwestern and Central counties, Burns reaffirmed his conservative ideas on social issues. This shift enhanced his position among White conservatives, but jeopardized his support among Blacks. Burns conservative turn occurred just as Jacksonville's Civil Rights movement intensified. As he hardened his opposition to integration, African American leaders reacted by organizing protest to force the city to integrate. By midyear 1960, the city faced massive NAACP sponsored protest and demonstrations. The NAACP wanted to integrate Jacksonville's public facilities and improve economic opportunities for Blacks. Jacksonville's African American community had many things for which to complain about. Despite the desegregated lunch counters most restaurants remained segregated and most Whites continued to ignore 44 percent of the city's population. The Florida Times Union Jacksonville's local newspaper devoted only two pages to covering African American news. These were the infamous star pages. Meanwhile, Black police officers could not arrest Whites nor exhibit their guns in the presence of Whites. ${ }^{14}$

The NAACP had a long successful history of fighting for Black rights in Jacksonville. Since its founding in 1917 by James Weldon Johnson, Jacksonville's NAACP chapter had gone through a series of successful presidents. The first president was Reverend John R. Scott. He was followed by Johnny Grey, Dr. C.F. Duncan, Robert T. Thomas, Theodore Redding, Glen Washington and then Rutledge Pearson followed in succession. Most Black leaders in Jacksonville were members of the organization and volunteered time to it. The NAACP had successfully organized African Americans for activities ranging from voter registration to cultural expositions. The local leaders felt comfortable handling racial problems because they were familiar with city officials. ${ }^{15}$

Rutledge Pearson as leader of the youth council led most 
NAACP sponsored demonstrations, while Frank Hampton, a wealthy political activist, filed law suits challenging discriminatory practices in Jacksonville's city parks and golf courses. In response to the city's recalcitrance, the NAACP opened citywide protests and demonstrations. After witnessing the success of sit-in campaigns in North Carolina, Pearson and his assistants organized training sessions to train students to lead sit-in demonstrations. He enlisted the aid of prominent attorneys like Earl Johnson and Ernest Jackson to counsel the students on their rights during sit-in campaigns. By law anyone had the right to sit at a lunch counter, but the storeowner did not have to serve you. The legal advice was followed by a series of lectures on the Christian principles of nonviolence which were generally lead by prominent Black ministers. These ministers used sermonic tones to remind the students to remain nonviolent no matter what the provocation..$^{16}$ After the initial training sessions, NAACP leaders organized a series of sit-in demonstrations that proved ineffectual because Whites refused to negotiate. These demonstrations ended, but after a series of meetings, the Youth Council decided to reopen the campaign. The NAACP renewed its demonstrations on Saturday, August 13, 1960, and planned to continue them until storeowners desegregated their lunch counters. The students first targeted Woolworths in downtown Jacksonville. ${ }^{17}$

Woolworth's had a White lunch counter positioned in front of the kitchen that had eighty-four seats and a fifteen seat African American lunch counter, in the rear of the store, hid behind garden plants and tools. Rodney Hurst led eighty-two students, in the first demonstration. They made small purchases from one counter and then sat at the White lunch counter and attempted to order lunch. They wanted to show the ridiculousness of being allowed to order from every counter except one in the same store. ${ }^{18}$ The store's manager closed the lunch counter, which was the demonstrators' goal. They wanted to close down the lunch counter, forcing the store to lose money. Pearson believed that if the lunch counters remained closed long enough, store owners would give in. There were sympathetic Whites who refused to buy where Blacks could not buy. Also, some White Navy wives held seats for the student demonstrators. ${ }^{19}$ Despite the nonviolent nature of the demonstrations things seemed ominous. In an August 24 Florida Star editorial, Eric Simpson warned, "Despite the relative calm that exists here the Negroe (sic) people in Florida, and particularly Jacksonville are faced with many,... problems that have led to unrest in other parts of the country." He went on to warn that unless city leaders joined with the business community and meet with Black leaders there would be violence. ${ }^{20}$

Simpson's words proved prophetic. The next day, two young demonstrators, running from the police, accidentally knocked an elderly White woman through a plate glass window. On August 26, a scuffle broke out between a White and Black female in front of a store where the latter was picketing. The two women knocked several White women to the pavement during their scuffle. This incensed the White community, and many drove to Sears and Roebuck and bought ax handles. Sears sold over fifty ax handles in fifteen minutes. ${ }^{21}$ On August 27, a group of Klansmen and White Citizens Council members from South Georgia and Northern Florida armed with ax handles, baseball bats, golf clubs and heavy walking sticks held a rally in downtown Jacksonville. They wanted to warn merchants and others not to violate Florida's segregation laws. Police officers patrolling the area did nothing as the Klansmen passed out leaflets signed the "Segregation Forces of Duval County" and threatened downtown merchants with citywide boycotts if they gave in to African American demands. $^{22}$
Pearson and a group of youth council members drove through downtown Jacksonville just before 9:00 a.m., to check out a report that men in Confederate uniforms were handing out ax handles at Hemming Park. The report proved accurate. Later that morning, the NAACP held a somber meeting at the Laura Street Presbyterian Church and decided to go ahead with a scheduled sit-in. However, they switched the store from Woolworth's to Grants located three blocks away at the corner of Main and Adams. ${ }^{23}$ At 11:00 a.m., about twenty-five students met at the Grant store, entered, made small purchases and took seats at the White lunch counter. At 11:37 a.m. the store's manager closed the lunch counter and forced the students out. As the students left, they noticed between 150 and 200 White men carrying ax handles and baseball bats running towards them. The frightened teenagers immediately ran for cover, but nearby store owners locked their doors to keep the panic-stricken demonstrators out. The Klansmen brutally attacked the students. ${ }^{24}$

At noon, a few African American protesters met in the downtown area for a scheduled demonstration. The group grew to about 3,000 peaceful protesters. The demonstrators, who were joined by some of Jacksonville's gang members, stood in the same area the Klan had stood just a few hours earlier. The Klansmen taunted and then attacked them also. Jacksonville's police officers were conspicuously missing. Whites who passed by gained satisfaction from watching Klansmen pummel unarmed peaceful protesters. A Catholic Priest who witnessed the ugly incident said, "If Christ walked the streets of Jacksonville, he would be horrified." ${ }^{25}$ Calvin Lang, who was walking home after visiting his mother who worked in a downtown store, remembers watching a group of Whites chase a young man down the street and hit him in the back of the head with a baseball bat. There were teenagers trying to climb palm trees as Whites chased them and beat them with sticks. The Klansmen chased the teens through the city and into the adjoining Black neighbourhoods. When they got into the Black neighborhoods the Boomerrang gang counterattacked the Klansmen. ${ }^{26}$

Armed with guns, knives, sticks, bottles, and molotov cocktails, they chased the White men out of the area. Lang said, "I will never forget how angry we were that these White men had come from out of town and attacked our neighbourhoods." He went on to say, "I remember seeing a group of Boomerrangs, throwing coke bottles through the windows of the newly built Robert Meyer Hotel. The Hotel had a glass face and they were trying to break out every window they could." Lang believes the Boomerrangs saved the African American community from damage by, forcing the Klansmen to leave the area. According to Lang, "The thing which upset us most was, that Mayor Burns was out of town and therefore, these White men from Georgia were allowed to raise sand in Jacksonville with no problem." ${ }^{27}$ Arnett Girardeau, a dentist and former activist, referred to the event as, "Axhandle Day". Blacks met violence with violence. "You had groups who were the prodding groups and then there were those who were the demonstrators. ${ }^{28}$ The demonstrators would take the abuse and the prodding groups would not take the abuse and would not allow you to abuse the demonstrators." A Florida Times Union reporter estimated that, at least fifty people were wounded in the melee. A White driver shot and wounded two Blacks after they attacked his car. Wayne Heidler, a White taxi cab driver, suffered facial burns when Black youths threw lye or potash on him when he stopped for a red light in an African American neighborhood. ${ }^{29}$

In another reported incident, William Howard Pellham, a sixteenyear-old White male, was stabbed in the chest after his car was 
stopped by a Black male in the downtown area. By the time the police arrived several African Americans had suffered head injuries from ax handles. The sudden violent outbreak ended three weeks of peaceful NAACP led sit-in demonstrations. The city used more than 200 police officers to end the violence. The police arrested sixty-two people on charges ranging from disorderly conduct to inciting to riot. Of those arrested, forty-eight were Black and sixteen were White. By night fall the police had the situation under control although sporadic violence continued. ${ }^{30}$ The blame for the rioting must fall squarely on Burns's shoulders. His recalcitrant attitude and political maneuvering caused the rioting. As Eric Simpson wrote, "It is clear that the disinterested attitude that our city fathers have shown to the Negro citizens' problems has brought on this terrible catastrophe that has visited us." He wrote that lunch counter integration that came about in other cities with little resistance occurred when the two sides sat and talked. Then quoting from the Tampa Tribune he wrote, "Sadly for Florida's reputation, Jacksonville could have had it this way but Mayor Haydon Burns turned it down. He revealed that a variety of store operators came to him several weeks ago to open their lunch counters to Negroes, but he told them not to do so." 31

Jacksonville's police department must share the blame. Police officers delayed intervening and disarming the combatants. It is unclear whether Burns ordered them to wait or that sixty-two year old Police Chief Luther Reynolds made the decision on his own. The police gave Klansmen time to punish the demonstrators and then arrested a disproportionate number of Blacks. In an editorial filled with invective, Simpson wrote, "It is the police duty to disperse at the onset, not to wait until, weapons in hand, they head for each other. The constitutional right to peaceful assembly does not include sanction for guns, knives, baseball bats or ax handles at the gatherings." 32 State NAACP leaders converged on Jacksonville to advise local officials. They also urged the Eisenhower administration to investigate the slow police response. E. Frederick Morrow expressed the administration's concerns to local leaders, while Attorney General Herbert Brownell promised an official investigation. The NAACP's Atlanta office sent Ruby Hurley to conduct an NAACP investigation into what went wrong? ${ }^{33}$

Local NAACP officials asked Burns to create a biracial committee to discuss the problems. He flatly refused arguing that biracial meant integrated and he would not foster integration. Meanwhile, state NAACP representatives announced an end to the sit-ins and a cooling off period. Florida Governor Leroy Collins placed the National Guard on alert and Burns had all 400 police officers along with Naval Shore Patrol units, patrolling the city. On August 28 local NAACP officials announced a citywide boycott of all places that practiced segregation. They also advised Blacks against purchasing the Florida Times Union because it slanted news stories and ignored news about the Civil Rights Movement. ${ }^{34}$ Members of the Chamber of Commerce, however, met with local NAACP leaders at the Snyder Memorial Methodist Church to discuss a solution. Chamber members were afraid of the economic impact of a prolonged boycott so near to the holiday season. Later, the Community Advisory Committee, an allWhite organization, met with an all-Black group with the same name. The two groups worked out an agreement that desegregated some department store lunch counters and promised better jobs for African Americans along with token desegregation in other areas. Mary Ann Pearson and Willye Dennis were hired as librarians becoming the first two African Americans to work in public buildings. Around the same time the Interstate Commerce Commission ordered the integration of all bus, and railroad terminals. ${ }^{35}$
Pearson and his family paid a price for their protest activity. He lost his job as coach of the Stanton baseball team, and his wife and children were forced into hiding to escape the many threats the family received. However, the NAACP won a partial victory. In April 1961, Marjorie Meeks who served as secretary of the youth council and Rodney Hurst the council's president went to downtown Woolworth's every day for a week and ate lunch at the previously all-White lunch counters. After the week ended, lunch counter segregation in Jacksonville's downtown stores officially ended. Segregation in downtown restaurants continued, but store owners gave vague promises about revisiting the issue later. The failure of this agreement led to the renewed demonstrations in 1964 as Whites equivocated on their agreements. ${ }^{36}$ The swift action taken by local NAACP officials during the riots resulted in the promotion of some NAACP leaders. In 1963, NAACP officials elevated Pearson to the presidency of the state chapter, giving him control over Florida's fifty-nine NAACP branches. Pearson's mandate was to continue the struggle to end segregation in Jacksonville. NAACP officials clearly hoped that Pearson could duplicate the success he had in Jacksonville. In two years he turned the fledgling Jacksonville branch NAACP into a major force for Civil Rights, increasing membership from a few hundred to well over 2,000. He was the first state NAACP leader to build a wide based coalition that included teachers, civic leaders, the business community, politicians, and ministers. In late 1962, Rodney Hurst resigned as Youth Council President and joined the Air Force. James Rapley replaced him. ${ }^{37}$

Pearson built solid community support for his civil rights activities. By embracing all levels of the Black community he had something to offer everyone. This made the task of recruiting help much easier. He had an easy time galvanizing support when he opened campaigns. Unfortunately, the agreements that he worked on were only as secure as the word of those he negotiated with. The ineffectiveness of the 1960 agreement made it obvious that Blacks would have to reopen their assault on local businesses to improve employment opportunities in downtown stores. ${ }^{38}$ The 1960 riots were important for setting the stage for the later stages of the Civil rights movement in Florida. Burns used the riots to sure up his racially conservative position in Florida. He used the momentum from this campaign to catapault himself into the Governor's mansion during the next election. Rutledge Pearson also gained important as he was promoted to president of the Florida Chapter of the NAACP. He was responsible for coordinating the NAACP sponsored Civil Rights throughout the state. This made him a national figure and increased his visibility. Just four years later the two men lock horns again. Again Burns would be in a close gubnatorial race while Pearson will be coordinating protest.

In 1964 when Jacksonville again found itself in the center of the civil rights struggle, Rutledge Pearson again found himself in the middle of the storm. As an agreement to end the 1960 rioting fell apart, Pearson once again did battle with Mayor Haydon Burns. As Burns made his second run for governor, the city he ruled once again exploded in rioting. The city experienced rioting as once again the NAACP pressured the city to end segregation. Pearson again distinguished himself during the protest. Though the demonstrations turned violent, Pearson was noted for his staunch determination to condemn the violence and keep the focus on nonviolent protest. He was praised for the way he and the NAACP conducted their protest.Though much of the nation's attention was centered on St. Augustine, where Dr. Martin Luther King, Jr. was leading a direct action protest, Jacksonville's residents were having their own protest lead by Rutledge Pearson. As Burns attempted to gain the democratic 
nomination for governor, Pearson used the opportunity to press city leaders to end segregation. From March through June 1963, Black residents protested segregation. This protest eventually led to a riot which gained international attention. The most violent period was in March 1963. ${ }^{39}$

Pearson was also noted for his work to improve education of Florida's minority children. In 1964 Pearson played an integral part in organizing a school boycott to force the city to speed up the process of integration in Jacksonville. The protest worked better than the planners expected. More than 17,000 students skipped classes during the boycott. As an employee of the school system, Pearson took a risk even though he did avoid any open support of the boycott. Pearson found himself in court defending his actions. The school system tried to charge the boycott organizers with blackmail. However, after a tense trail, the boycott leaders were vindicated. Even though he won the case he saw the handwriting on the wall and made the difficult decision to leave the teaching profession..$^{40}$ In August 1966 Pearson accepted a job as business agent working for the Laundry Dry Cleaning and Dry House Workers Union. The paid more money than teaching and also provided a free automobile. On May 1, 1967 Pearson was traveling to lead a strike against the New York Steam Laundry in Memphis when his car traveling at $80 \mathrm{mph}$ skidded off a rain soaked road and crashed into a bridge abutment in Waynesboro Tennessee. Pearson was killed in the crash. Florida's civil rights struggle immediately knew it had s lost an important soldier. Both Jacksonville and the state of Florida knew that there would not be another person like him. It was no surprise when more than 5,000 people crowded into the Shiloh Metropolitan Baptist Church in Jacksonville, Florida to participate in his funeral services. Almost all of them came to show their respects for a man who gave his life to make theirs better. ${ }^{41}$

Pearson's contributions to Florida's racial progress can be summed up by some words his daughter, Patricia Pearson, uttered "I remember that we received several phone calls over the years from the Confederate underground, saying that we were going to die, but regardless of these efforts, the tide of racial segregation, discrimination and injustice turned because both black and white, young and old people in Jacksonville were empowered to fight." Rutledge Pearson armed African Americans in Florida with the weapons they needed to free themselves from the racial miasma they found themselves in. He lead the struggle which took Florida from a backwater to the center of the civil rights struggle in the US. His contributions to Florida can never be forgotten nor can we forget the victories he was responsible for. Pearson spent his life fighting for others and attempting to make the state he called home a better and more open place for those who looked like him.

\section{Acknowledgments}

None.

\section{Conflicts of interest}

The author declares that there is no conflicts of interest.

\section{References}

1. Missing Pages in the Jacksonville Story. Duval County Public Schools 1972-3. Biography Rutledge Pearson, Jacksonville Public Library, Haydon Burns Branch. 1972

2. Ibid. Native Son. Jet. 1964;52-53.
3. Lanctot. Neil Negro League Baseball: The Rise and Ruin of a Black Institution. Philadelphia: University of Pennsylvania Press. 2004;112-114

4. St. Petersburg Times. 1964

5. Jacksonville Journal. Interview Rodney Hurst. 1995.

6. Ibid. Jacksonville Journal. "Jacksonville Native Son," 53; Interview Commander Martin P Garris. Jacksonville, Florida. Interview William Lassiter Jacksonville, Florida, March 18, 1998. William Lassiter says he was impressed by the courage shown by black leaders during that period. 1998.

7. Florida Times Union, January 22, 2008.

8. Native Son. Jet. 1964;52-53.

9. Ibid. Interview: Frank Priestly teacher Isiah Blocker school in Jacksonville. 1995.

10. Interview. Marvin Dawkins, Tallahassee. Florida. 1996.

11. Interview. Mary Ann Pearson widow Rutledge Pearson in Jacksonville, 1994. Florida Times Union. 2008.

12. Interview Reverend Charles Dailey. Pastor of the Oakland Street Baptist Church and Head of the Jacksonville Branch Interdenominational Ministerial Alliance, by telephone January 5, 1995; Interview Lloyd Pearson, by telephone at his home in Jacksonville. Florida. 1996.

13. Ibid, Erick, Dittus. Jacksonville's Black Community is Still Searching for The Promised Land. Jacksonville Today. 1988;38.

14. Interview. Rodney Hurst. 1995. Florida Times Union. 1993.

15. St. Petersburg Times. Interview, Mary Ann Pearson widow Rutledge Pearson in Jacksonville, 1994. Promise of Trouble. 1960;27.

16. Bartley. Abel Keeping the Faith: Race, Politics, and Social Development in Jacksonville. Florida. 1940-1970. Westport: Greenwood Press. 2000;97-98.

17. Ibid BH. Walch New Black Voices: The Growth and Contributions of Sallye Mathis and Mary Singleton in Florida Government. Jacksonville, 1990, 75. “Jacksonville's Native Son,” Jet. 1964;52.

18. Interview Mary Pearson. Jacksonville, Florida, February 17, 1996. Personal papers in her file taken from NAACP records. The NAACP had successfully organized African Americans for activities ranging from voter registration to cultural expositions. Native Son, Jet, 54.

19. Bartley. Keeping the Faith, 98. Walch New Black Voices75. Native Son. Jet. 52 .

20. Interview. Lloyd Pearson. 1996, 1998. Jacksonville: Florida. 1998

21. Interview. Rodney Hurst 1995. Florida Times Union. 1993.

22. Florida Star. 1960.

23. Ibid. New York Times 1960. Florida Promise of Trouble. 1960;27.

24. Racial Fury Over Sit-ins. Life. 1960;37.

25. Ibid. Interview Lloyd Pearson based on information provided by his sons Alvin Kent and Lloyd III who participated in the sit-ins and were arrested. New York Times. 1960.

26. Interview. Calvin Lang, Tallahassee. Florida. 1993.

27. Ibid. Florida Times Union, 1983. Florida Times Union, 1960. Walch: Black Voices. 74

28. New York Times. Florida Times Union. Jacksonville Journal. New York Times. 1964.

29. Interview Commander Martin P. Garris. Jacksonville, Florida. 1998. 
30. Ibid. Interview, Commander Martin Garris. Jacksonville, Florida. 1998.

31. Ibid. Promise of Trouble. Time. 1960.

32. Interview Rodney Hurst. New York Times. 1964.

33. Walch. Black Voices 75, Interview, Mary Ann Pearson, 1995. Jacksonville. Florida: Interview, Willye Dennis. 1995.

34. Interview. Rodney Hurst. Also see Abel A. Bartley Keeping the Faith Race Politics and Social Development in Jacksonville, Florida 1940-1970. Westport: Greenwood Press. 2000.

35. Florida Times Union. Interview, Rodney Hurst. 1991.
36. Florida Star. Native Son. 1963;53..

37. Florida Star. Florida Times Union. 1964.

38. Florida Times Union. Toward a Long Hot Summer. Time. 1964;28-29.

39. What's Behind Jacksonville's Race Violence. Jet. Pittsburgh Courier. $1964 ; 19$.

40. The Pearson award brochure. Jacksonville Public Library Haydon Burns Branch. African American files Rutledge Pearson folder, Florida Collection. Florida Times Union, 1991. Jacksonville Journal. 1982;115.

41. Florida Times Union. 2008. 